\title{
阪神・淡路大震災後の「白地地区」における住民主体 のまちづくり活動の事例研究
}

\author{
A Case Study of Community Design in Shiroji- Area on the Reconstruction Process, after the Great \\ Hanshin-Awaji Earthquake
}

\begin{abstract}
浅野智子* 野嶋政和*
Satoko ASANO Masakazu NOJIMA

摘要 : 本稿では阪神・淡路大震災後の「白地地区」の復興の現状および組織運営のあり方を事例的に 検証することを目的とする。神戸市須磨区天神町 3.4.5丁目を事例地とし、1996 年 7 月〜1999 年 3 月を調查期間にアクションリサーチを行い, 事例地のまちづくり活動の特質について, まちの復興プ ロセスにおける1公共空間整備の方向性，2 2住民参加の可能性の観点から，実証的に把握した。その 結果, (1)当地区の住民の活動が震災後の公共空間整備への展開の可能性を有すること. (2)当地区の自 治会を住民を代表する組織として復興プロセスに関与していく可能性と，活動を継続していく限界性 を有することが明らかになった。
\end{abstract}

\section{1.はじめに}

阪神・淡路大震災後の被災地の復興では, 震災によって顕在化 した，既成市街地の抱える空間的諸問題を克服するため，細街路 の拡幅，公園設置などの地域のオープンスペースを整備する必要 があろう"。本稿が扱う「白地地区」に関しては，上記のような 空間整備に対する公的施策が積極的には講じられず，住民が自主 的かつ組織的に取り組む必要がある。震災後 5 年を過ぎた時点で は，復興に関する議論で，「白地地区」2)に抢ける住民の取り組 みの事例報告は概して少なく，また空間的課題が川積した状沙で あること がが報告されている。

こうした現状からは，「白地地区」の復興プロセスに抢ける住 民と行政, 専門家の空間整備の実践に向けたパートナーシップの 必要性は益々高まっているといえる。同時に空間操作 に関わる 我々専門家にあっては，研究領域において，上記の実践に資する ような地域計画への住氏参加に関する計画論の構築, またその為 の事例研究の蓄積が求められよう。既にこうした要請から, まち づくりにおける専門家の計画支援の必要性や復興プロセスにおけ る行政とまちづくり協議会とのパートナーシップの現状と課題等 が指摘されてきた。本稿では，住民の主体的な活動を実証的に 把握することを通して,「白地地区」の復興の現状掞よび組織運 営のあり方を検証する ${ }^{6)}$ 。このことは，住民の取り組みを「仅対 運動に終始する」なよ゙の限界性においてではなく”彼らがより主 体的に震災後の既成市街地の復興に関わる可能性をむつ，まちづ くりの萌芽として理解する契機となり得るだろう ${ }^{8 !}$ 。住民の組織 運営に着目した既往研究では, 計画プロセスに㧍ける住民の協働 作業や組織間の対立を調整する機関の必要性が指摘されてきた

本稿では事例地のまちづくり活動の特質を，まちの復興プロセ スにおける，(1)公共空間整備の 方向性，および(2)住民参加の可 能性の観点から明らかにする。 本稿では, 神戸市須磨区天神町 $3 \cdot 4 \cdot 5$ 丁目 $^{10\rangle}$ を事例地として， 1996 年 7 月〜 1999 年 3 月を調 查期間に，事例地の自治会が主

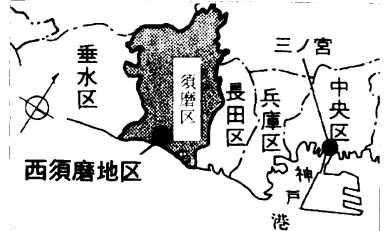

図-1 事例地の位置 体的に進める活動に実践的 表-1 事例地の人口と世帯数推移 に関与するアクションリサー ヂを行った。本稿の構成

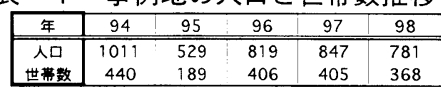

は以下の通りである。(1)事例地の自治会のまちづくり活動を概観 する( 2 節)。(2)まちづくり活動初動期における震災後のまちの課 題之活動への参加の実態を把握する( 3 節)。(3)活動開始から 2 年 半の間のまちの課題への取り組みの成果之住民の活動への自己評 価を把握する(4 節)。(4)以上の調查・分析結果から事例地のまち づくり活動の特質を明らかにする( 5 節)。

\section{2. 調査地の概要とまちづくり活動の流れ}

事例地は須磨区の南西部に位置する（図-1，図-2）。明治 より住宅地として発展し, 戦災や戦後の区画整理を免れ, 震災前 は古い密集した木造家屋と細街路が多く残った。地区の北端には 山陽電鉄が，東端には 2 東線の離宮道が走る。また旧西国街道が 当地区を東西に貫通し，その沿道は近隣商業地区であるが，他の 大部分は第一種住居専用地域である。公共施設は，離宮道を挟ん で，震災時に避難所となった小学校がある。

当地区も震災によって甚

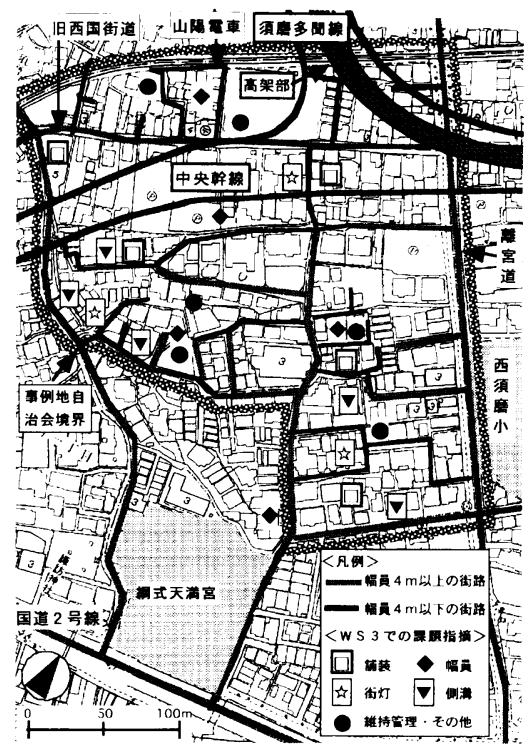

図-2 事例地の概要と生活基盤整備の 課題 (WS 3 の結果) 大な被害を受け年（表一1）, 復嬹計画では復興促進地域 に指定された。当地区を含 む西須磨地区には，震災前 から神戸市の交通ネットワー ク整備として幅員 22〜36 $\mathrm{m}$ の中央幹線・須磨多聞線・ 下森線が計画決定され， 1989 年から地区整備計画 に基づき区画整理による事 業化が構想されたが，自治 会の合意が得られず頓挫し た。震災後, この3 路線か 復興計画として事業認可さ れ，買収等の事業が進めら れている ${ }^{13)}$ 。

当自治会の活動の流れ之 本稿で取り上げる調査概要 を表- 2 にまとめた。活動 の全体的推移は, 96 年 7 月の自治会再編以降，10

*京都大学大学院農学研究科 
月までの活動準 備, 97 年 3 月 までは主にまち の課題の共有お よび組織運営体 制の確立，それ 以降は課題別の 取り組みと新た な課題の組み込 みの継続である。 まちの課題への具体的な取り組み内容と成果は後述する（表一 1)。 事例地においては，住民を巻き込んだ活動を展開する為に，(1) 自治会役員会から住民に対して, 活動の提案＝前回の活動成果の 総括および次回の活動テーマ設定と, 参加の呼びかけ＝広報, 資 料を作成する作業，(2)住民から役員会に対して，集会等の活動で の課題提起や活動への提案する作業を往復していくことが, 基本 的な組織運営方法として採用された。本稿のワークショップ （以下WS）は, 少人数のグループを編成し, 集扵面接により被 験者の意見を収集する意識調查方法であり，得られた意見は各々 個別データとして扱い, KJ法 ${ }^{15)}$ を用いて分析を行った。

\section{3. 活動初動期におけるまちの課題と活動への参加の現状}

本節では事例地で 1996 年 7 月 1997 年 3 月の活動初動期に実 施された 3 回のWS およびアンケート方式による住民意識調查 結果から, (1)震災から 1 年半後のまちの課題の現状について, WS によるまちの課題の関係構造（質的分析）により把㨦し，ア ンケート調査による課題認識の重み

（量的分析）から検証する。また(2) まちづくり活動開始から半年間の, 住民の自治会活動への参加状況之課 題認識との関係について, アンケー 卜調查結果を中心に分析していく。

本節では, 《事例地の住民意識の 全体構造》之《各課題内容とその相 関関係》に分けて記述する。

（1）WSによる意識調査結果

(i) 調查, 分析方法

WS $1 \sim 3$ で, まちの課題につい ての意見收集が行われ, 計 365 件の 意見が得られた。分析は以下の手順 で行った。

WS 1〜2 は活動テーマおよび作 業内容が同質であるため,デー夕を 統合した後, 小分類した。さらに(1) 事例地の震災後の空間的課題の復興 プロセスにおける位置づけ，(2)復興 に関わる主体間の関係, (3)住民の活 動の方向付け，の分析軸を設定して， 各カテゴリーの関係を構造化した (図一-3)。WS 3 のデータは, 作業 がオリエンテーリングで作業テーマ が限定されたことから, 参考デー夕 として図一3に適用し，収集された 生活基盤の課題の位置は図 -2 に示 した。以下本節（1）で］１各図 表のまちの課題の見出し,「」は小 見出し、『』は調查時に記録した住 民の意見の抜粋である。

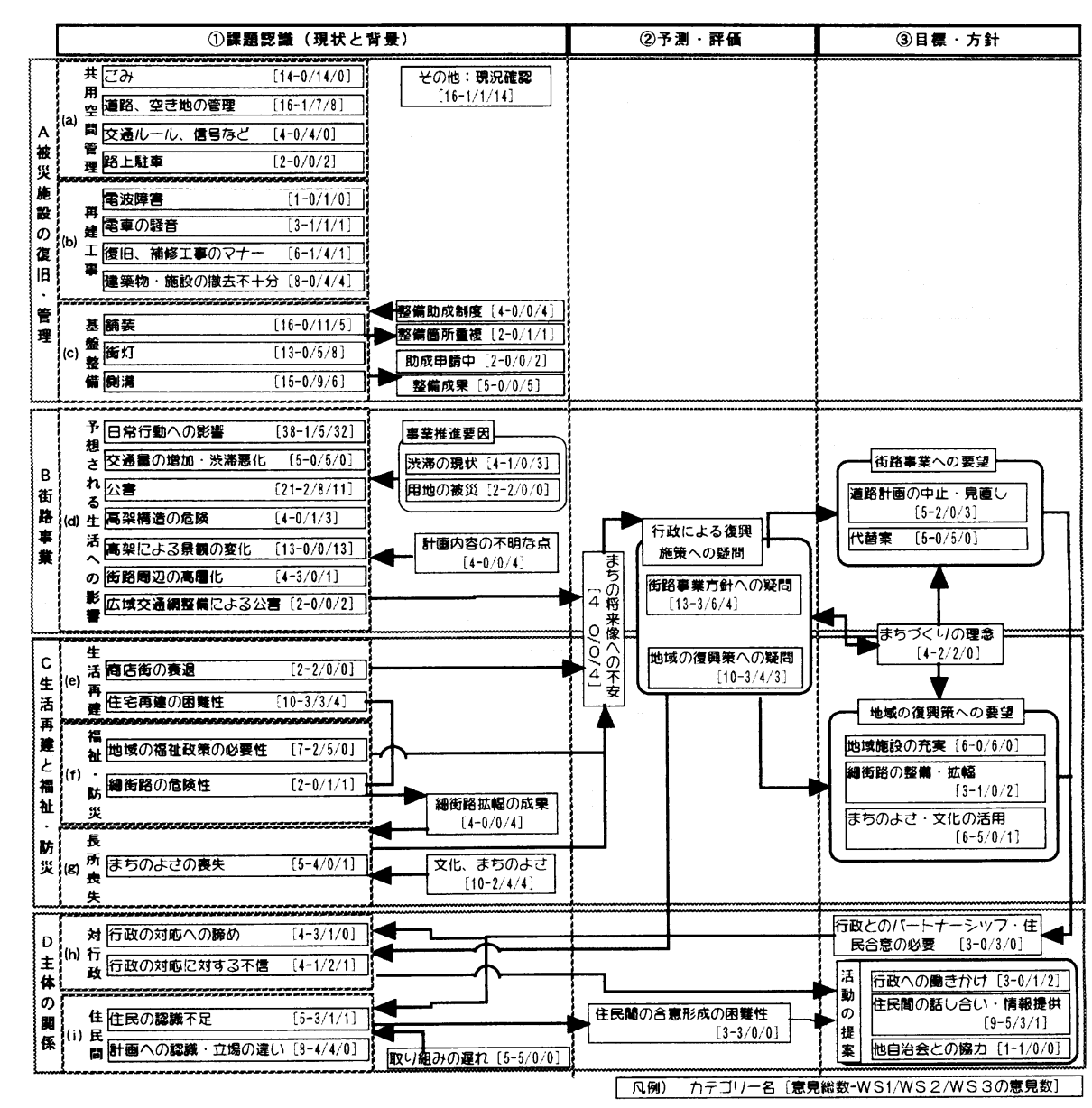

図－3 まちの課題の構造（WS 1 ～ 3 の結果） (ii) まちの課題の関係構造

《全体構造》住民が提起したまちの課題は, 図一 3 の縦軸にあ たる $\mathrm{A} \sim \mathrm{C}$ : 空間的課題々 D : 課題に関わる主体間の関係に大別 される。空間的課題は, $\mathrm{A}$ : 被災した生活基盤の震災前の状態へ の復旧・再建に関わる課題, B : 復興計画として行政が事業化決 定した街路事業, C：长期的な視点でまちの将来像を模索する生 活再建之福祉・防災の課題に分けられる。一方各カテゴリーは, 住民の活動上の位置付けから, 図一-3横軸の(1)課題認識, (2)予測・ 評価, (3)目標・ノj針に分類される。

全体的な意見分布を見ると $\Lambda \sim \mathrm{C} の$ 空間的課題では，Aは課 題が列举され, 意見数も多いが, 他の課題との関連は少ない。 は課題のなかで最も意見数が多く，Cは相対的に意見数は少ない。 さらに住民活動の展開の面から各カテゴリーの関係を見る上， BCD の課題は, (1)課題認識から(2)予測・詊価や(3)月標・方針に 関わっており，住民の復興への取り組みの主要軸といえる。

WS 1〜3への意見数の推移を見ると, WS 1 では1）に関する 
表 $-3-1$ アンケート調査参加者の基本属性

\begin{tabular}{|c|c|c|c|c|c|c|c|c|}
\hline T目 & \begin{tabular}{|c|} 
3 T目 \\
96 \\
\end{tabular} & $\frac{4 \mathrm{~T} \text { 目 }}{82}$ & \begin{tabular}{|c|}
$5 \mathrm{~T}$ 目 \\
38
\end{tabular} & & & & & \\
\hline 年粠 & \begin{tabular}{|c|}
10 t \\
\end{tabular} & $\frac{20 \text { 代 }}{7}$ & \begin{tabular}{|c|}
30 代 \\
14 \\
\end{tabular} & $\frac{40 \text { 代 }}{43}$ & $\frac{50 \text { 代 }}{62}$ & $\frac{60 \text { 代 }}{56}$ & $\frac{70 \text { te }}{26}$ & $\frac{N A}{6}$ \\
\hline 性踏 & $\frac{\text { 男 }}{76}$ & $\begin{array}{c}\text { 女 } \\
128\end{array}$ & $\frac{\mathrm{NA}}{12}$ & & & & & \\
\hline 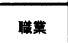 & $\frac{1 \text { 町内自兽 }}{31}$ & $\frac{\text { 町外自䒤 }}{25}$ & \begin{tabular}{r|} 
サラリー \\
41
\end{tabular} & $\begin{array}{l}\text { 主蝙 } \\
67\end{array}$ & 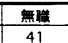 & $\frac{\text { 学生 }}{3}$ & zの地 & $\begin{array}{l}\text { NA } \\
4\end{array}$ \\
\hline $\begin{array}{l}\text { 震災後の } \\
\text { 住居 }\end{array}$ & \begin{tabular}{|c|} 
前と同 \\
117 \\
\end{tabular} & 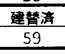 & & $\begin{array}{l}2 \lambda \\
27 \\
\end{array}$ & $\begin{array}{l}\text { 定出予定 } \\
5\end{array}$ & $\begin{array}{c}\text { zの他 } \\
4\end{array}$ & $\begin{array}{c}\text { NA } \\
1 \\
\end{array}$ & \\
\hline
\end{tabular}

意見が多く，特に住民の「取り組みの遅れ」や今後の活動方針と しての「話し合いの必要性」が指摘されている。WS 3 ではBの 街路事業の[予想される生活への影響] で多くの指摘があり，才 リエンテーリングにより住民に事業内容への認識を喚起すること が推祭される。WS3ではAとCに関して, 各々基盤整備や細 街路拡幅の成果が·部で確認されている。

《空閏的課題の内谷之相関関係》

(1)被災した施設の復目 ・管理〈A-1 $\rangle$

住宅や被災施設の [(b)再建 [. 事] の課題や，これと関連した [(a)共用空間の管理]の思化が指摘された。街路施設なよ゙の $[(\mathrm{c})$ 基盤整備]では特に私道整備の際の関係者の合意や業者選定なよ゙ 整備助成手続き」と関係吉る。細街路が多く, 街路空間の整備 が末だ進んでいないことが理解される。（脳-2）

(2)街路事業（須磨多聞線，中央幹線）〈B-1)

街路供用後の, 地域空閣利用の变化なよ゙の「日常行動への影響 や「交通量の増加」による「公害」，「景観への影響」などの [(d) 予想される生活への影響]への不安が大きい。こうした不安は, 䈍交通量，宫架の詳細設計なよ゙「計町内谷の不明な点」により 増大され，「まちの将来像への不安」に結びっく。

·方「街路事業の推進要团」として, 震災前より当地风に見ら れた「交通啮滞」や，「事業用地の建物の被災」が大きいなかで， 地権者が建物の『建て替えが出来ない』状沙が指摘されている。

表 $-3-2$ まちの課題認識および取り組み意識, よいところへの認識

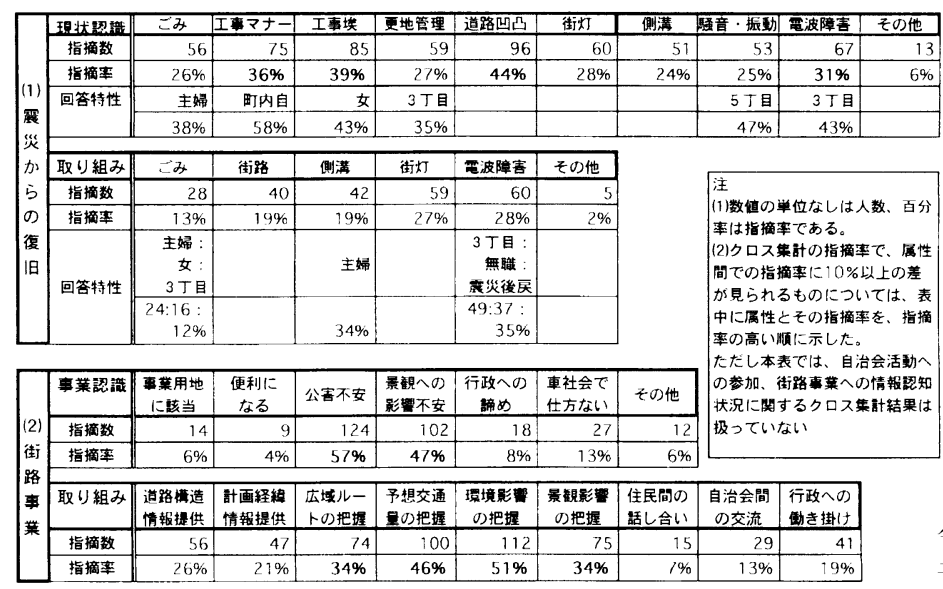

(3)生活再建と福祉・防災〈C-(1) $\rangle$

壁面後退の義務，再建資金の不足による「住宅の再建の困難性」, 「商店街の衰退」など震災後, 個々人の [(e)生活再建 $]$ の難しさ が挙げられた。

公共的な側面からは「細街路の危険性」や，集会所などの公共 施設整備や福祉制度の充夹といった，地域の総合的な [(f)防災・ 福祉対策]の必要性が提起されている。他方で細街路の搪幅によ る交通量の増加や『住宅の再建で街並みが变化』したなよ゙，既成 市街地の肯定的な性質である伝統行事や街並み, 路地の纷井気な よ゙，まちの [ $(\mathrm{g})$ 長所が撣失 $]$ してることがある。

(4)行政による復興施策への疑問〈B-(2)/C-(2)〉

1:䛉B-(1)，C-1)の, 街路事業之住宅再建と福祉・防災への認 識は，『天神町は駄目になってしまう』という「まちの将来像へ の不㚣」と「行政による復興施策への疑問」に関連していく。 [行政による復興施策への疑間] では，Bに関しては，計画街路 が住宅地を縦断するという事業内谷や予想交通量が不明なことか ら「計画力針・有用性に対する疑問」が示された。Cでは『地域 サービスより街路事業を優先』しているなよ゙, 街路事業と対比さ せる形で「地域の復興支援策への疑問」が挙げられだ。これらは, (5)に示す B 抢よび C に関する住民からの提案を導く一方で行政 の対応への不信に結びっく。

(5)住民によるまちづくりの提案〈B-3/C-3)

『子よ゙もたち屯住み続けられるような』などの「まちづくりの 理念」が提起され，これに基づき， B と C 各々に関して要望が あげられている。

ト記の(2)〜(5)に示した，Bの街路事業および C の住宅再建之 福祉・防災の課題に対する認識は，Dの主体間の関係について の課題認識に結びついている。

《関係主体間の関係に関する課題の内容之相関関係》 (1)関係立体に関する課題認識〈D-(3)/D-1) $\rangle$

住民のニーズに合うまちづくりを進める条件としての D-3)「行政とのパートナーシップ・住民合意の必要性」 の認識は，D-1)の関係主体間の関係に関する課題を提 起している。D-1)では, 行政については, 震災後の街 路事業に対する住民の反対や計画の見直しの『要望，質 問への誠実な回答がない』等,「行政の対応に対する不 信」がある。一方，こうした現状で，住民にも「諦め」 や，情報不足による「住民の認識不足」「事業認識，立。 場の違い」が課題として挙げられている。

(2)住民の活動への評価〈D-(2)〉

震災前に，行政より街路事業着手が提示されていたが, 住民が『取り組もう之思ったら地震』があり, 震災後も 混乱により「取り組みの遅れ」があったと評価された。

今後の展開においては住民間の「住民合意形成の困難さ」が 予測されているが，行政と住民との関係性については言及さ れず，今後の展開の不透明さを反映しているといえる。

(3)今後の活動の提案〈D-(3) $\rangle$

今後の活動では，関係主体への㗢きかけが提案されているが， [(h)対行政］より屯「(i)住民間] の方が意見数が多く，震災後 1 年半を経てまちづくり活動に取り組むにあたり，住民側の組織的 基盤をつくるための活動が提案されている。行政に対しては，街 路事業への対忍を中心として，住民が「働きかけ」ていくことが 挙げられている。

（2）アンケートによる意識調査結果

(i) 調查, 分析方法

アンケート調查の質問項目は，（I）回答者属性などの基本事 項，（II）まちの課題および，まちのよいところへの認識，（III） 自治会活動への参加状況，評価等加らっている。（II）のまち 
の課題は，既述のWS による意識調查の分析結果に 即し, (1)震災からの復旧, (2)街路事業, (3)生活再建上 福祉・・防災に大別した。さらに(1)〜(3)の課題每に, 図一 2 の(a)〜 (i)小見出し中の課題から設問項目を抽出し, 各項目の現状と今後の取り組み要望に対する認識の有無を 複数回答で調べた。但し本節（2）の（iv）で述べる街路 事業の認知の程度は 3 段階で設問した。まちの長所への認 識は項目を改めて設定した。

分析方法は単純集計および回答者属性, 自治会活動への 参加状況，情報認知状況の面からクロス集計を行った。ま た各々の結果から，指摘率（指摘数/有効回答者数または クロスした属性者数）を算出した。回答者属性とのクロス 集計結果で，他の属性との指摘率が $10 \%$ 以上の差がある 場合は, 表 3-2 で回答特性の参考データとして提示する。 （ii）アンケート調查の実施状況（表-3-1）

アンケート調査の回收率は全世帯の $98 \%$ である。震災 前からの住民が多く, 54\%が震災前之同じ住宅に住んでい る。

\section{（iii）まちの課題への認識の重み（表-3-2） 《全体構造》}

まちの課題では, 課題の現状, 取り組み認識とも街路事 業が高い指摘率で $50 \%$ 以上の住民が関心を示した。続い て震災からの復旧, 生活再建之防災・福祉対策の順である。まち のよいところへの意識は高く, 設問項目中で最も高い指摘率を示 し，70〜80\%の住民がまちのよさを評価している。

まちの課題への現状認識と今後の取り組みについての質問が共 に設定された課題では, 全般的に後者が低く, 平均で 4 ポイント 下がっており，僅かながら現状認識と今後の取り組み意識との差 を示している。また属性によるクロス集計結果では, (1)震災から の復旧で丁目毎に整備の必要な筒所が認識された。

《各課題への住民の認識》

(1)震災からの復旧「舗装」や「街灯」などの生活基盤や「再建 工事」に関する課題認識が高い。

(2)街路事業「公害」「景観への影響」への指摘率が約 50\% と, 住民の街路事業への不安の大きさが確認された。「便利になる という積極的に肯定する評価は少ないが，「行政の対応が強引で 諦めている」「車社会なので仕方ない」等, 事業主体や世論への 消極的な反応は若干高い。

今後の取り組みでは「環境への影響」「交通量の把握」などの 情報提供が約 50\%，事業の基本的情報の収集も20 30\%で，事 業内容に関する情報不足が窥える。しかし「住民間の話し合い は7\%，「行政への㗢きかけ」は19\%とやや低い結果である。 (3)生活再建之福祉・防災「遊び場」や「集会所」の不足，「細 街路の危険性」の指摘率が $30 \sim 40 \%$, 地域拠点の整備が不十 分であることが認識された。今後の取り組みでは「訪問介護制度 の情報提供」が指摘され住民の高齿化への不安を示している。 （iv）活動への参加状況之課題認識の相関関係

本節では自治会活動への参加有無と情報認知，およびまちの課 題認識との関係について, アンケートのクロス集計の結果, その 関係が顕著であった街路事業との関係を取り上げて分析する。

《自治会活動への参加状況（表 $3-3$ )》


加内訳は住民集会, 総会, 説明会上も15\%前後である。参加し たことが有る人数とその内訳の人数の比からみると, 分散して参 加する傾向がある。今後の活動への参加では，アンヶートへの協 力，集会への参加がそれぞれ $56 \% ， 23 \%$ であり，集会への参加 の意向を示した人数は, 参加有の人数より低く, アンケート調査 の目的とは，むしろ対照的な結果である。

表 - 3-4 まちづくり活動への参加および街路事業認知の程度と 街路事業認識および取り組み意識との相関関係

\begin{tabular}{|c|c|c|c|c|c|c|c|}
\hline \multirow{2}{*}{\multicolumn{2}{|c|}{ 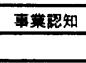 }} & \multicolumn{2}{|c|}{ 車亲の存在を不知 } & \multicolumn{2}{|c|}{ 央菜の存在のみ慨知 } & \multicolumn{2}{|c|}{ 事荣存在 ·内容既知 } \\
\hline & & 人数 & 指摘率 & 人数 & 指摘事 & 人数 & 指墒重 \\
\hline Elent & & 8 & $4 \%$ & 101 & $47 \%$ & 93 & $43 \%$ \\
\hline 参加 & $\begin{array}{l}\text { 有 } \\
\end{array}$ & 0 & $0 \%$ & 17 & $27 \%$ & 38 & $62 \%$ \\
\hline 状況 & 無 & 5 & $3 \%$ & 80 & $57 \%$ & 51 & $36 \%$ \\
\hline
\end{tabular}

(2) まちづくり活動への参加および街路事業認知と事業認識との相関関係 洼)

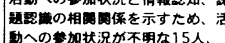

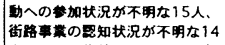

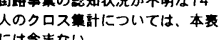
过はまない

\begin{tabular}{|c|c|c|c|c|c|c|c|}
\hline 事菜配識 & 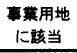 & $\begin{array}{c}\text { 便利に } \\
\text { なる } \\
\end{array}$ & 公寒不安 & $\begin{array}{l}\text { 影错への } \\
\text { 晾番不安 }\end{array}$ & \begin{tabular}{|c|} 
行政への \\
語の
\end{tabular} & \begin{tabular}{|l|} 
車社会で \\
仕方ない
\end{tabular} & その他 \\
\hline 有 & $7 \%$ & $3 \%$ & $69 \%$ & $64 \%$ & $8 \%$ & $13 \%$ & $8 \%$ \\
\hline 無 & $6 \%$ & $4 \%$ & $53 \%$ & $41 \%$ & $9 \%$ & $14 \%$ & $5 \%$ \\
\hline 存在不知 & $0 \%$ & $0 \%$ & $0 \%$ & $0 \%$ & $0 \%$ & $0 \%$ & $0 \%$ \\
\hline 存在のみ祀知 & $7 \%$ & $3 \%$ & $53 \%$ & $42 \%$ & $8 \%$ & $12 \%$ & $3 \%$ \\
\hline 存在 - 内容毗知 & $8 \%$ & $7 \%$ & $71 \%$ & $61 \%$ & $10 \%$ & $16 \%$ & $16 \%$ \\
\hline
\end{tabular}

(3) まちづくり活動への参加および街路事羳認知と今後の取り組み意識の関係

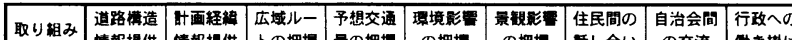

\begin{tabular}{|c|c|c|c|c|c|c|c|c|c|}
\hline & 情墥提供 & 情報提供 & 上の把暒 & 量の把暒 & の把塬 & の把暒 & 恬し合い & の交流 & 䘄表搕け \\
\hline 直 & $33 \%$ & $26 \%$ & $31 \%$ & $48 \%$ & $59 \%$ & $34 \%$ & $18 \%$ & $23 \%$ & $33 \%$ \\
\hline 無 & $24 \%$ & $21 \%$ & $36 \%$ & $47 \%$ & $51 \%$ & $37 \%$ & $3 \%$ & $11 \%$ & $15 \%$ \\
\hline 存在不知 & $0 \%$ & $0 \%$ & $25 \%$ & $0 \%$ & $0 \%$ & $13 \%$ & $0 \%$ & $0 \%$ & $0 \%$ \\
\hline 存在のみ盟知 & $24 \%$ & $22 \%$ & $48 \%$ & $55 \%$ & $56 \%$ & $35 \%$ & $2 \%$ & $5 \%$ & 13 \\
\hline 存在 - 内容路知 & $30 \%$ & $25 \%$ & $24 \%$ & $44 \%$ & $56 \%$ & $40 \%$ & $13 \%$ & $25 \%$ & $28 \%$ \\
\hline
\end{tabular}

《活動への参加と街路事業認知の相関関係（表 3-4-1)》

回答者の $47 \%$ 「街路事業の存在のみを認知」しており,「事 業の存在之併せて事業内容も認知」しているのは $43 \%$ に留まる。 調查が震災から 2 年が経過した時点であることを考慮すれば, 事 業内容の認知度が高いとはいえず，情報把握の難しさを示してい る。計画の情報の認知の程度と集会への参加の有無の関係からは, 集会に参加している住民が情報を認知する傾向がある。

《活動への参加㧍よび街路事業認知上, 事業認識㧍よび取り組み 意識之の相関関係（表3-4-(2), (3))》

「街路事業の存在と内容を認知」と「集会への参加有」が, 事業の存在のみ認知」と「参加無」に比べ, 多くの項目におい て指摘率が高い。「生活, 健康」「景観への影響」の不安では前者 2 項之後者 2 項で約 20 ポイントの差が現れている。今後の取り 組みへの意向でも「他自治会との協力」「行政への働きかけ」に 関しては前者 2 項之後者 2 項では約 15 ポイントの開きがある。 (3) 小括

事例地の住民のまちづくり活動の初動期における住民意識調查 より, 震災から 1 年半〜 2 年が経過した時点での当地区のまちの 課題と活動への参加の実態について以下のことがわかった。 (1)当地区のまちの課題は空間的課題之その解決に関わる主体間の 関係に関する課題に分けられることが, WS 結果より示された。 (2)空間的課題のうち, WS 結果では街路事業之生活再建㧍よび福 祉・防災の課題が当地区の復興の主要軸であった。街路事業は, 公害の不安や計画に関する情報開示の面で住民の関心が高いこと がアンケート結果より実訨された。福祉・・防災対策は住民が抽象 的な範网内で整備方針や提案を持つことがWS 結果で示された。 (3)まちの空間的課題の解決にあたっては, 住民と行政とのパート ナーシップの必要性が認識されているが, 行政に対しては不信感 があることがWS 絬果より示された。また住民に関しては諦め や立場の違いがあることがWS，アンケート結果より実証された。 (4)当自治会の活動では, アンケート調査への高い参加が見られた。 しかし今後の行政や住民への働きかけの要望や住民の活動への参 加の意向はやや低いことがアンケート結果より示された。

(5)住民の活動への参加が, 住民にまちの課題に関する情報を提供 し課題への関心を喚起すると共に, 住民や行政等の関係主体に働 きかける必要性を認識させる傾向がアンケート結果から窺える。 
表 -4 まちの課題への取り組みの推移とその成果

\begin{tabular}{|c|c|c|c|c|c|}
\hline \multirow{2}{*}{\multicolumn{2}{|c|}{ 续題 }} & \multirow[t]{2}{*}{ 96年度の活㲜 } & \multicolumn{2}{|c|}{ 97年度の活動 } & \multirow{2}{*}{ 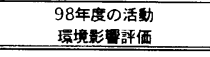 } \\
\hline & & & 整定整篇 & 噮境影警棓俩 & \\
\hline & こ一处理 & 公当番制の導入 & & & \\
\hline \multirow{4}{*}{ ( } & 驾き地管理 & 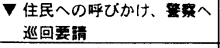 & & & \\
\hline & 街灯整满 & 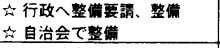 & & & \\
\hline & 電波噇書 & 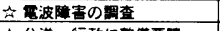 & & & \\
\hline & 街路鋪琵 & 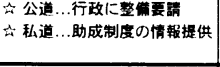 & & & 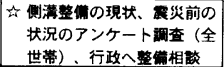 \\
\hline \multirow{3}{*}{ 街 } & $\mid \begin{array}{c}\text { 行政への意 } \\
\text { 志表示対市 } \\
\text { 交涉 }\end{array}$ & 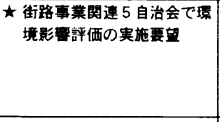 & 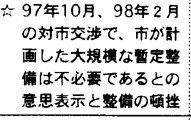 & 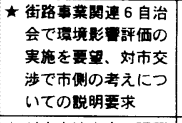 & 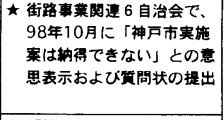 \\
\hline & $\left|\begin{array}{c}\text { 住民間での } \\
\text { 情報の共有 } \\
\text { 舕し合い }\end{array}\right|$ &  & 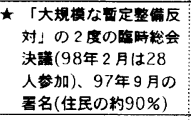 & 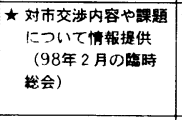 & 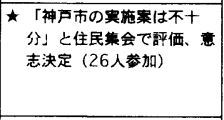 \\
\hline & $\begin{array}{c}\text { 他自治会と } \\
\text { 協力 }\end{array} \mid$ & 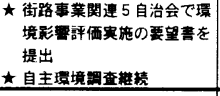 & 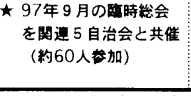 & 太交涉の方針について & 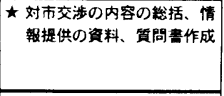 \\
\hline \multirow{4}{*}{$\begin{array}{l}\text { 福 } \\
\text { 裃 }\end{array}$} & 街並み保全 & & \multicolumn{2}{|c|}{ 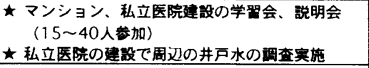 } & \\
\hline & \begin{tabular}{|c|}
$\begin{array}{c}\text { 防犯。防炫 } \\
\text { 对策 }\end{array}$ \\
\end{tabular} & 太消火拴の位䨌確现 & & & \\
\hline & 福祉对策 & & \multicolumn{2}{|c|}{ 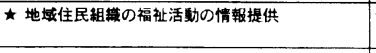 } & 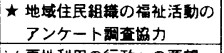 \\
\hline & 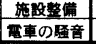 & マコミュニティ・ホール助成 & & & V更地利用の行政への要㖏 \\
\hline \multirow{3}{*}{$\begin{array}{l}\text { 自 } \\
\text { 治 } \\
\text { 会 } \\
\text { 䪹 } \\
\text { 点 } \\
\end{array}$} & 厷報 & 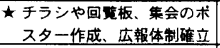 & & & \活動報告書の発行 \\
\hline & 超熋者䕗絡 & 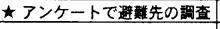 & & & \\
\hline & \begin{tabular}{|l|} 
地域行專 \\
活坋助成 \\
\end{tabular} & & & & \HAR加活動貫金助成 \\
\hline \multicolumn{3}{|c|}{ 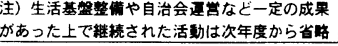 } & \multicolumn{3}{|c|}{ 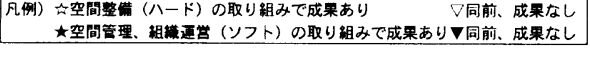 } \\
\hline
\end{tabular}

表一 5 まちづくり活動への自己評価

\begin{tabular}{|c|c|c|c|}
\hline & 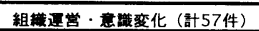 & \multicolumn{2}{|l|}{ 空間（壾14件） } \\
\hline $\begin{array}{l}\text { 活動への } \\
\text { 加の } \\
\text { きっかけ }\end{array}$ & 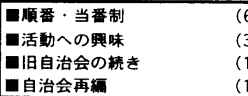 & 口区画整理、街路亲 & (2) \\
\hline $\begin{array}{l}\text { 活 } \\
\text { 個 } \\
\text { の }\end{array}$ & 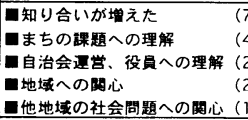 & 回生活道路の整備 & (1) \\
\hline 果 & $\begin{array}{l}\text { 回住民間、家族でまちのことを } \\
\text { 話し合えるようになった } \\
\text { 日自治会の円滑な運嘗 }\end{array}$ & & \\
\hline $\begin{array}{c}\text { 活動の } \\
\text { 課题 }\end{array}$ & 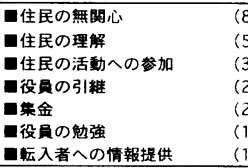 &  & $\begin{array}{l}\text { (4) } \\
\text { (3) } \\
\text { (2) } \\
\text { (1) }\end{array}$ \\
\hline その地 & $\begin{array}{l}\text { 口自治会再編までの経縝 } \\
\text { 口自治会の理念 }\end{array}$ & & \\
\hline
\end{tabular}

街路事業への対応では自治会内での住民間の情報共有 ～他自治会之の協力〜行政交渉之意志決定の 3 つのレベ ルで対応している。基本的には住環境への影響の把握が 主眼となっているが，97年度はこれと併せて街路事業 用地の暫定整備計画へも対処している。

生活再建之福祉・防災については，地域施設整備に関 しては行政の担当部局之，福祉対策については地域の住 民組織上連携した取り組みを行っている。その他，集合 住宅や病院建設計画に対し，住環境保全の観点から説明 会等での建物階数, 施設配置確認を行っている。

自治会運営では広報体制の確立を中心に成果がある。98 年度 の活動報告書発行では，HAR 基金から助成を得，住民の他，行 政や周辺自治会, マスコミ, 市民団体へ当地区の活動に関する情 報を発信し，活動への協力を求めている。

（2）まちづくり活動に対する役員の自己評価

(i) 調查, 分析方法

自治会活動の成果㧍よび今後の課題について, 自治会の運営に 深く関わる役員層からWS による意見収集を行い，72 件の意見 を得た。得られたデー夕は, 空間的課題と組織運営の課題, およ び活動の評価の内容から分類を行い表一 5 にま之めた。

（ii）まちづくり活動への自己評価の内容

《全般的な構造》組織運営に関する指摘が多く, 空間的課題の評 価はその $1 / 4$ の意見数である。

《活動への評価》活動への参加は, 旧自治会からが 1 人で, 殆ど の役員が震災以降である。「参加以前から自治会活動やまちの課 題に関心をむって」より,「当番制」により参加したよいう指摘 が若干多く, 役員層でも活動に参加する段階では, 関心の程度が 多様で，自治会という基本的全戸加入組織の特徴が視える。

活動成果は，個人的には，役員を担当する区域での広報や署名 活動，会合への参加を通じて地域内で「知人が増えた」という指 摘が多く，特に担当区域内で独居する高歯者の所在の確認が挙げ られる。また街路事業や施設整備制度の情報共有や意見交換等に より，「まちの課題への関心!「他地域の景観問題や公共事業など の社会問題への関心」が生まれるなど, 学習的成果も指摘され, 総じて「住民間や家族などの多様なレベルでまちの課題について 話し合う」ような基盤が醸成されたとの評価がある。

活動の課題では, 「住民の無関心」「情報の理解度についての疑 問」が半数近くの役員から出され, 役員自身も情報を理解するこ とに負担を感じているという指摘もあるなど, 情報共有の難しさ を示した。組織運営ト:「役員引継」「集金」の課題もある。空 間的課題では，防災やコミュニティ活動の観点から，「細街路」 「地域拠点の整備」「街路事業などまちの将来」への不安等の八一 ド面での成果が獲得されていないことが指摘された。 
(3) 小括

事例地の住民のまちづくり活動開始から 2 年半の間の, 住民の まちの課題への取り組みの内容およびその成果と, 役員層の活動 への自己評価の聞き取り調查により以下の点が明らかとなった。 (1)まちの課題への取り組みにより, 生活基盤整備ではハード面の 成果が見られた。街路事業や福祉・防災は, 長期的には八ード面 の空間整備を目標としながら, 個々の活動事態はソフト面での対 応が中心で，ハード面での具体的成果は得られていない。 (2)署名や集会などでは多数の参加者があり, 役員層の活動への自 已評価でも住民間のネットワークの形成での成果が挙げられた。

·方, 役員層からは, 住民の無理解, 無関心等, 活動を継続して いくにあたって住民への働きかけの難しさが指摘されていた。

\section{5. 考察}

本節ではこれまでの分析をふまえ，住民と行政とのパートナー シップによる公共空間整備を目指した事例地の住民のまちづくり 活動の特質について, (1)まちの復與の力向性とまちづくり活動の 条件，(2)まちづくり活動の実態と今後の活動の展開より考察する。

\section{（1）まちの復興の方向性とまちづくり活動の条件}

事例地では住民の主体的なまちづくり活動により, 当地区の震 災後の空間的課題が把握された。特に街路事業は, 住民の関心も 高く, 震災後のまちのあり方を問うものとして認識された。しか し当地区の復興計画である街路事業は，住民が単に「反刘運動」 を展開する対象としてではなく，まち全体の復興という枠組みか ら, 住民が震災後のまちの現状を総体的に捉える機会として位置 づけられている。さらにこのことは, 行政の復興事業に対して, 住民が，福祉や防災対策など，まちの公共空間整備を中心とした 復興のオルタナティブを構想する契機となっている。

したがって，当地区の住民は，まち全体の復興にあたっては， 住比之行政とのパートナーシップよ住民合意が必要であることを 認識していた。しかし住民は，パートナーシップについては，震 災後の街路事業の認可や，住民の望む復興支援が得られない状況
から行政への不信感を示していた。他方住民合意については，住 民のまとまりを重視してもいた。以上より，震災後 1 年半を経た 時点で当地区の住民がまちの復興に関わるためには，行政が交涉 相手として認めるような住民組織の編成が必須であり，その作業 を，自治会活動を通して住民が主体的に担ったことがわかる。

\section{（2）まちづくり活動の実態と今後の活動の展開}

当地区の住氐の組織化の実態を詳しく見ると，まちづくり活動 では多様な方法が採られ，多くの参加者を得ながらも，住民の活 動への参加に対してはやや消極的な姿勢も見られた。また活動へ の評価でも，住民への働きかけの難しさか潧念されている。当地 区では，活動を通じて自治会を基盤とした住民組織の運営体制が 確立されてはきたが，実際には，住民に積極的に働きかける役員 層が，活動を実質的に担っていたことがわかる。

空間的課題への取り組みの成果を見ると，長期的なまちの復興 に向けた公共空問整備の成果は得られていない。街路事業を巡る 住民氐行政之の協議が進展せず，行政之のパートナーシップが形 成されない現状では，住民の求めるまちの空間的課題の解決の目 処は文なない。即ち，住民の継続的な取り組みに拘わらず，住民 之行政之の関係により，まちの復興が成され得ない状況では，住 民の立体性のみに依存した活動には限界があることを意味する。

\section{6. 結論}

本稿より事例地のまちづくり活動の特質として，(1)当地区の住 民の活動が震災後の公共空間整備への展開の可能性を有すること (2)当地区の自治会を住旦を代表する組織として復興プロセスに関 与していく可能性と, 活動を継続していく限界性を有することが 確認された。以上より，「白地地区」の復興プロセスに㧍いて， 住民と行政のパートナーシップが重要であること，そしてパート ナーシップ形成に向けた住氏の活動を継続的に支援する社会的枠 組みが不可欠であることが再確認される。

本稿の調查にあたり，大神町 $3 \cdot 4 \cdot 5$ J日自治会の多くの方々 の協力を得た。ここに改めて感謝の意を表す。
参考文献・註

1) (社) 日本都市計画学:会防災 - 復與開題特別 委員会（1999）：安全上再生の都市づくり 学芸出版社, (社) 日本都市計画学会防災 · 復興問題研究特別委員会第 2 部会計画支援・ 住民参画部会（1997）：住民主体の復興まち づくり中間報告書, 造景 No1 (1996)：建築 資料研究社などを参照。

2 ) 震災復興促進地域のう5, 重点復興地域に 指定されず, 行政より地域の復興のための 面的事業が提示されない地区を指す。前揭 書を参照。事例研究では，安場浩一郎他 (19 96）: 阪神淡路大震災以後の神户市須磨区に 打ける復興計画に関する住民意識の研究 ランドスケープ研究 59,253-256, 浅野智 子他 (1996)：阪神・淡路大震災後の神亚市 須磨区に打ける住民のまちづくり活動に関 する研究：ランドスケーフ研究 59,257 261 .

3 ) 安藤元夫他（1997）：木造密集书街地の細街 路，狭小宅地に书汀る住宅再建の困難性に 関与る研究：都市計画論文集 32，751-756。 重村力他（1998）：被災住宅方街地の再建過 程の研究：日本建築学会計画系論文集第 513 号，219-225，芦屋市が対象の野澤千絵他 （1998）:被災地の住宅の個別再建によ万街 区内災害路の变化に関吉る研究：都市計画
論文集 $32,847-852$ 等。

4) Hルフェーブル (1974) : 都小革命 : 晶文社

5 ) 復興プロセスへの住民参加に関する論考上 しては参考文献 1 ) 第 2 部, $209-294$ な上 在参昭。

6 ) 特集「安全上再生の都市づくり」について の座談会 : 都书計画 217 (1999), 25-34, また神戸市真野地区での住民のた体的な取 り組みの展開を報告している吉風健次他(19 81): 大都市の衰退と再生：東京大学出版会 などを参照。

7 ) 住民の反対運動の空閒計画への叮能性に関 寸る卯月盛夫 (1999)：ドイッの都市計画に 果たす市民団体の役割に関する考察：日本 建築学:会計画系論文集第 520 号, 271-278 なよ゙を参照。

8) A.メルッチ（1996）：現在に生きる遊牧民 岩波書占, M.力ステル (1997)：都书とグ ラスルーツ：法政大学出版局，を参照。

9) 福田由美子他（1993）: 住民主体の計画づく りに扔けるコラボレーションの考察: 都市 計画論文集 28，55-60，岡崎篤行他（1994）: 歴史的街严みを生かしたまちづくりのプロ 七スに打ける合意形成に関する事例研究： 都市計画論文集 $29 ， 697-702$ ，森永良内他 (1995) : 「状況づくり」の視点からみた参 加型集住体計画の研究：日本建築学会計画
系論义集第 478号, 69-78等。

10）事例地の白治会のまちづくり活動は，天神 町 3・4・5丁目自治会 (1999)：わがまち 21 世紀に向けて〜まちづくりのあゆみ〜を 参照

11)ソーシャルワーカー上してある種の役割を 果たしながらフィールトワーク在続ける夹 践的研究在指す。須藤健一他 (1996)：フィー ルドワーク在歩く: 嵯峨野書院など。調全 結果を活動にフィードバックした，瀬戸円 剛（1991）：公时賃貸住宅居住者が主体とな

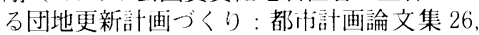
637-642 を参照。

12）95年は国勢調榃，他は住民基本台帳による。 後者は転居届等の手続きによる数值である。 アンケート調查上の世帯数の差は，当時の 地区内の居住者在主な対象上した為と考え られる。

13）西須磨まちつうくり懇談会（1997）：住民主体 への挑戦：工ピック社，桜木町自治会 (19 96）: 桜木町自治会意見書等を参㬎。また事 例地は千森線からは外れている。

14）浅海義治他（1993）：参加のデザイン道具箱： 世田谷まちづくりセンターなどを参照。

15）川喜多二郎 (1976) : 発想法 : 中央公論社, また前掲の森永良队他（1995）などを参照。

Summary : Tenjin-cho 3-4-5 cho-me, Suma Word, Kobe City, is one of the called "Shiroji- Area" on the reconstruction process, after the Great Hanshin-Awaji Earthquake, as no support have been given from municipal government. In this article, we report the process of the residents $\beth$ activity, analyze their consciousness of the problems of their community and evaluation of their activity,. As a result, the following is made clear. The residents are eager to participate in the reconstruction process and have been engaged in solution of their problem. But it is difficult to management and get result of their activity, because they are in conflict with Kobe City government on artery projects and have no support yet. 